Article

\title{
Nutrient Reduction in Agricultural Green Infrastructure: An Analysis of the Raccoon River Watershed
}

\author{
James F. Canning ${ }^{\dagger}$ and Ashlynn S. Stillwell *,+ (iD \\ Department of Civil and Environmental Engineering, University of Illinois at Urbana-Champaign, \\ Urbana, IL 61801, USA; jcannin2@illinois.edu \\ * Correspondence: ashlynn@illinois.edu; Tel.: +1-217-244-6507 \\ + Current address: 205 N. Mathews Ave., 2521 Hydrosystems Laboratory, Urbana, IL 61801, USA.
}

Received: 6 April 2018; Accepted: 28 May 2018; Published: 8 June 2018

\begin{abstract}
Agricultural intensification has had the undesirable effect of degrading water quality throughout the United States. Nitrate pollution presents a difficult problem for rural and urban communities, and it contributes to the immense Gulf of Mexico Hypoxia Zone. Current U.S. policy prohibits regulation of agricultural runoff because it is a nonpoint source. The Raccoon River Watershed upstream of Des Moines, Iowa, USA has some of the highest nitrate levels in the nation, and the drinking water utility in Des Moines unsuccessfully pursued litigation against drainage districts in the watershed. We propose a cooperative solution between urban residents and upstream rural residents-namely, the installation of agricultural green infrastructure in the form of riparian buffers throughout the watershed enabled by the principles of water quality trading. We compare this distributed, green approach with a centralized, gray approach (i.e., building a new nitrate removal facility at the drinking water utility). Using terrain analysis, we determined that first-order streams are the most fitting location for riparian buffers. We estimate the buffer installation to cost between $\$ 155-\$ 185$ million; maintenance of the current nitrate removal facility will cost $\$ 72$ million, while a new facility could cost up to $\$ 184$ million. Riparian buffer installation offers more indirect, non-quantified benefits than maintaining or building new centralized, gray treatment (e.g., living-wage jobs and in-stream water quality improvement). Our analysis could act as a model for water quality trading and distributed agricultural green infrastructure in other communities facing similar water quality challenges.
\end{abstract}

Keywords: agricultural green infrastructure; nitrate; terrain analysis; water quality trading; conservation policy

\section{Introduction}

Agricultural intensification, including the widespread use of fertilizer and livestock manure, has led to increased inputs, improved agronomic practices, and enhanced crop varieties [1]. Intensifying agriculture is necessary to meet the demand for crops from an increasing global population (projected 2.3 billion person increase by 2050), but it comes with potentially hazardous environmental effects [2]. Dabrowski et al. [3] found that the water required to dilute polluted water to pertinent water quality standards is similar to the water quantity required to produce crops, indicating the extent to which fertilizer intensification affects water quality. The impairment of waters due to agricultural runoff is a problem for many rural and urban areas in the United States-a 2010 United States Geological Survey (USGS) study found that nitrates were above recommended levels in 64 percent of surface water and shallow groundwater monitoring wells throughout the United States [4]. Nitrates pose a 
threat to both human and aquatic life. Consuming nitrates has been shown to lead to two major health issues in humans, namely infant methemoglobinemia (or "blue baby syndrome") and cancers of the digestive tract $[5,6]$. People with weakened immune systems (babies, the elderly, and sick persons) are most susceptible to suffering sicknesses due to ingesting nitrate-polluted drinking water. Nitrates are also toxic to various fish species, and can lead to degraded health and increased mortality rates [7-9], in addition to contributing to eutrophication that further harms wildlife [10].

Furthermore, nitrogen and phosphorus pollutants have contributed to the growing Gulf of Mexico Hypoxia Zone, a dead zone that was measured at over $26,000 \mathrm{~km}^{2}$ in 2017 [11]. A hypoxia zone is typified of low dissolved oxygen levels, caused by nitrogen and phosphorus, that place large amounts of stress on aquatic ecosystems [12]. The Gulf of Mexico Hypoxia Zone is the second-largest on the planet after the Baltic Sea Hypoxia Zone [13,14], and it represents an immense water quality issue that impacts wildlife, and consequently humans, throughout the Gulf region. Agriculture in the Midwest is a significant driver of Gulf Hypoxia. Land covering over 50 percent of America's farms drains into the Mississippi River Basin. Reducing agricultural runoff and thereby water pollution would reduce the size and toxicity of the Gulf Hypoxia Zone, and such goals are the motivation for various nutrient load reduction programs throughout the 12 states comprising the Mississippi River Basin [15-17]. In many of these states, both rural and urban communities are urged to manage nutrients polluting their water.

Nitrate pollution levels in the Raccoon River Watershed (RRW) upstream of Des Moines, Iowa (Figure 1) are some of the highest in the nation [18]. Water flowing from the RRW is used as drinking water for the Des Moines metropolitan area, an area serving more than 500,000 people. Nitrate levels were consistently high enough (continually above the federal $10 \mathrm{mg} / \mathrm{L}$ maximum contaminant level) to force Des Moines Water Works (DMWW), the region's drinking water utility, to construct the world's largest nitrate removal facility [18]. Nitrates are costly to remove from water; DMWW spends between $\$ 4000$ and $\$ 7000$ each day to operate its nitrate removal facility [19]. Hatfield et al. [20] showed that the nitrate issue in the RRW has worsened over time. Since the 1970s, levels have increased, even with stagnant fertilizer use over the previous 15 years. Agricultural runoff is accountable for water quality violations in many other lakes, streams, and estuaries [21-23], and yet regulation of such runoff is not a viable policy solution. The Clean Water Act explicitly states in §502(14) that agricultural fields are exempt from federal permitting, meaning that farmers voluntarily introduce best management practices on their fields to reduce water pollution.

Although DMWW operates a centralized nitrate removal facility, there are distributed solutions to preventing nitrate pollution. We introduce the idea of "agricultural green infrastructure" in the form of riparian buffers. Agricultural green infrastructure functions similarly to its urban counterpart, infiltrating runoff and reducing the amount of pollutants reaching downstream. Its performance depends on topography, soil health, storm events, and other climatic conditions. We analyze riparian buffers as one agricultural green infrastructure practice intended to reduce nutrient levels. Buffers prevent the degradation of surface water through the uptake of nitrates by the vegetation, as well as facilitating conditions necessary for denitrification and phosphorus removal [24,25]. Nitrogen, phosphorus, and sediment pollution challenges exist in the RRW [26], representing one of the most nitrate-polluted watersheds in the United States. Jones et al. [27] analyzed 2016 data to determine that Iowa contributes 41 percent of the nitrate load to the Gulf of Mexico. Thus, the RRW is a fitting location for our analysis because of its large contribution to degraded water quality. Furthermore, it is the setting of a recently-decided, contentious lawsuit between DMWW and three upstream drainage districts (Bd. of Water Works Trs. of Des Moines v. Sac Cty. Bd. of Supervisors as Trs. of Drainage Dists. 32, 42, $65,79,81,83,86$, No. 5:15-cv-04020, 2015 WL 1191173). The lawsuit is a microcosm of a larger theme throughout the United States-a rural-urban divide that precipitates deadlock over environmental issues. The final ruling stated that water leaving the drainage districts was not regulated, and the districts did not have to recompense DMWW monetarily for having to treat the nitrate-laden water. The RRW is unique in the extent to which nitrate pollution has led to greater issues, and thus we chose it as the focus of our analysis. We attempt to answer the question of where riparian buffers might 
be placed throughout the RRW to reduce nitrate pollution. We further answer the question of what scale of cost would be required to install enough buffers to reduce nitrate levels below the federal drinking standard.

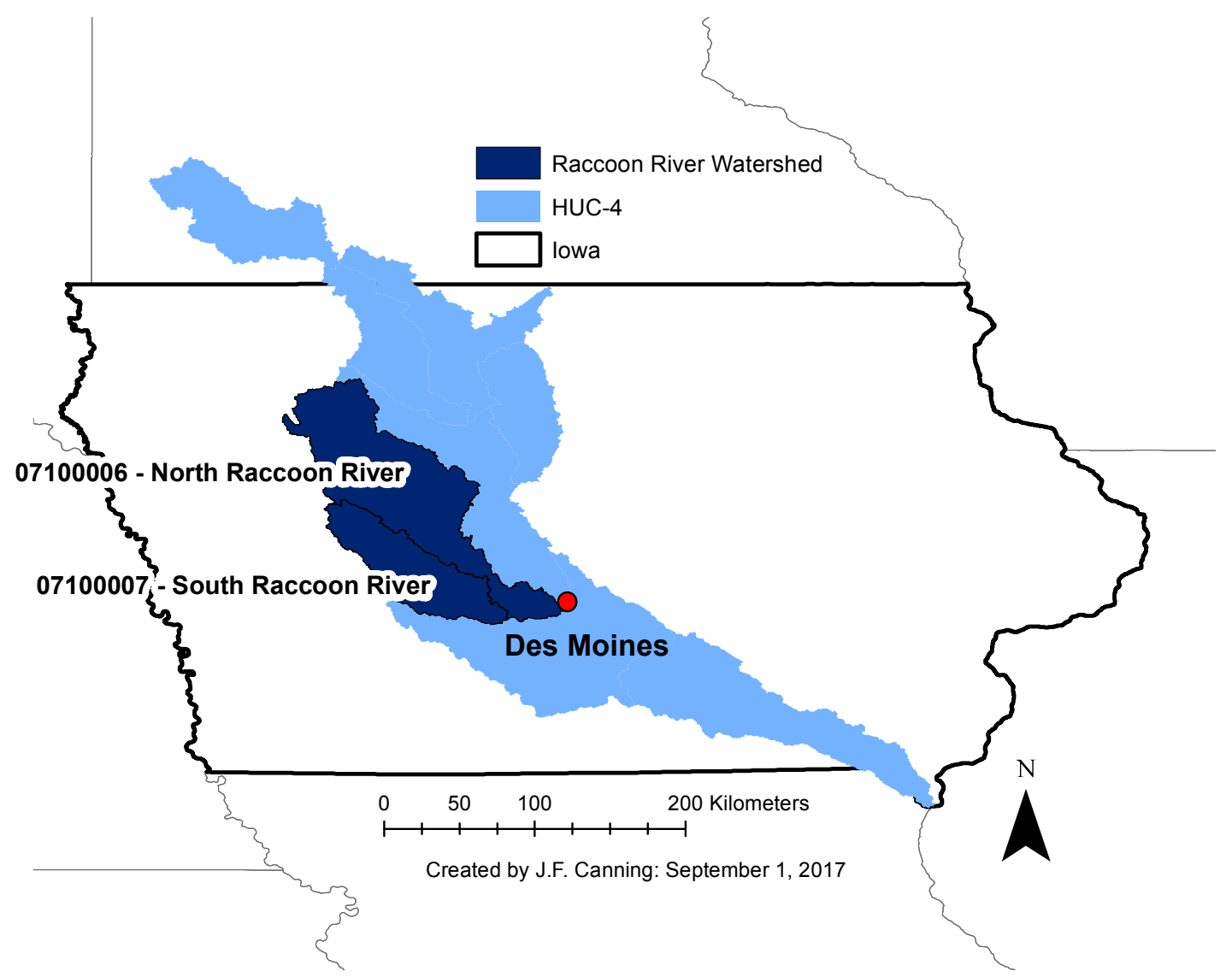

Figure 1. The Raccoon River Watershed (RRW), situated upstream of Des Moines, Iowa, USA, has some of the highest nitrate levels in the nation. Such high nitrate levels have led to negative environmental, economic, and social effects throughout the region and beyond. HUC-4: 4-digit hydrologic unit code.

Riparian buffers are often most effective along first- and second-order streams [28], where a majority of the runoff in a watershed begins and can be targeted. We utilized terrain analyses to determine where buffers might be most effective throughout the RRW. Terrain analyses determine topographically optimal locations with the most surface and subsurface flow where buffers will be most effective. Terrain analysis methods using geographic information systems (GIS) have proven effective at discerning fitting locations for buffers $[28,29]$. Using the results from our analysis, we designed a potential multi-species riparian buffer that could be used throughout the RRW. Buffer performance is dependent upon factors in addition to topography, such as soil type, water table height, and vegetation type, and so we created a design that can be amended as necessary. Using the principles behind water quality trading (WQT), we propose a partnership between DMWW and upstream agricultural operators as one possible solution to the immense nitrate problems faced by the watershed. We investigated two scenarios that DMWW (and Des Moines residents overall) could enact to address nitrate pollution: (S1) constructing riparian buffers throughout the entire RRW and (S2) installing a new nitrate removal facility (Table 1). We labeled the new nitrate removal facility as the centralized, gray approach, and the riparian buffer solution as the distributed, green approach, using language similar to urban stormwater management. We analyzed the economics of these potential solutions with the additional goal of presenting an example for other communities throughout the Mississippi 
River Basin. Water quality is an increasingly important issue, and innovative solutions are required to create sustainable changes, even while current policy cannot enforce such changes.

Table 1. Potential Des Moines Water Works nitrate control solutions. Current business as usual is not feasible because eventually the nitrate removal facility will become defunct and nitrate levels will reach levels above federal standards for drinking water. Thus, we do not consider it as a scenario. WQT: water quality trading.

\begin{tabular}{cc}
\hline Scenario & Description \\
\hline S1 & "WQT" Riparian Buffer Construction \\
S2 & New Nitrate Removal Facility \\
\hline
\end{tabular}

The RRW has been widely studied. Jha et al. [30] performed SWAT analyses (Soil and Water Assessment Tool, made available by United States Department of Agriculture (USDA) Agricultural Research Service), first calibrating the tool and then completing various sensitivity scenarios. The authors performed a sensitivity analysis in which they increased the amount of conservation land throughout the RRW, similar to our installation of riparian buffers. Hatfield et al. [20] presented data from the past 70 years to show how cropping practices, fertilizer use, and land use changes for certain crops have led to changes in nitrate levels throughout the RRW. Schilling and Zhang [18] broke down nitrate concentration data in Iowa to determine the proportion of baseflow that contributes to nitrate levels. Tomer et al. [28] performed terrain analyses in Iowa, focusing on the Keg and Silver Creek watersheds. Thus, the gap in literature concerning terrain analyses of the RRW precipitates the necessity of our present analysis. Furthermore, to our knowledge, there have been no studies contrasting centralized gray infrastructure and distributed green infrastructure in an agricultural context. Many studies analyze green versus gray infrastructure in urban, not agricultural, settings [31-33]. We add our present analysis to the greater body of knowledge in gray and green infrastructure comparisons.

\section{Background}

\subsection{Des Moines Water Works (DMWW) Lawsuit and Long-Term Policy Significance}

Polluted drinking water has become an increasingly divisive issue in Des Moines. On 16 March 2015, DMWW filed a lawsuit (Bd. of Water Works Trs. of Des Moines v. Sac Cty. Bd. of Supervisors as Trs. of Drainage Dists. 32, 42, 65, 79, 81, 83, 86, No. 5:15-cv-04020, 2015 WL 1191173) against drainage districts in three Iowa counties (Buena Vista, Calhoun, and Sac). DMWW alleged that the drainage districts, located upstream of Des Moines and draining into the RRW, illegally discharge polluted water from a point source (i.e., tile drains). DMWW contended that the runoff is indeed a point source and thus liable to the full regulatory requirements of the Clean Water Act [34]. DMWW has been operating a nitrate removal facility since 1991, and costs to remove nitrates have risen to between $\$ 4000$ and $\$ 7000$ per day [19]. If elevated nitrate levels continue, the utility will need to construct a new nitrate removal facility costing taxpayers between $\$ 76$ million and $\$ 183.5$ million [19]. There are 77 entities that discharge into the Raccoon River and must hold National Pollutant Discharge Elimination System permits, which require nitrate levels below $10 \mathrm{mg} / \mathrm{L}$ of effluent [35]. DMWW argued that the drainage districts must also remain below this nitrate threshold.

In January and March of 2017, after two years of deliberation, the final rulings in the DMWW lawsuit came from the Iowa Supreme Court and a federal judge, respectively. The former stated that the drainage districts were not responsible for costs incurred due to high nitrate levels, declaring that the drainage districts would not pay the $\$ 1$ million that DMWW was demanding. The federal judge argued that drainage districts lack the regulatory powers bestowed on other governmental entities, and furthermore, they were not depriving DMWW of the water, a common good, in the Raccoon River [36]. The judge abstained from ruling whether tile drains can be regulated as a point source. Thus, DMWW and other water quality stakeholders were forced to resort to encouraging voluntary 
conservation efforts and awaiting legislative action pertaining to nutrient pollution. Even though the courts decided the drainage districts are exempt from regulation and from paying for nitrate removal, the lawsuit could still have its desired effect. For example, the U.S. Environmental Protection Agency (EPA) could hand down a consent decree that forces a state to develop stricter regulations on agricultural runoff [19]. There are already 12 Midwestern states that have developed nutrient reduction strategies for this very purpose [15-17], but such strategies do not have direct regulatory power. The recommended best management practices are left up to farmers to voluntarily adopt. However, voluntary conservation efforts can be ineffective, and thus another approach might be needed for water quality stakeholders. Water quality trading is one such approach.

\subsection{Agricultural Green Infrastructure-Riparian Buffers}

Riparian buffers such as grass strips, riparian forests, or a combination of both can mitigate water quality degradation, attenuate flows running off fields, and reduce erosion [37,38]. Buffers can be established anywhere alongside a riparian corridor between a stream and the agricultural field (Figure 2). Hydrologically, buffer strips improve the infiltration of water through the propagation of macropores throughout the soil $[39,40]$ and enhance water holding capacity by adding organic matter and increasing porosity [41]. Buffers have been shown to retain or remove nitrate by 60-90 percent [42-44]. Denitrification in particular is efficient under suboxic conditions with plenty of available organic carbon. In the winter and early spring seasons, when susceptibility to erosion and nutrient leaching is highest, Burt et al. [45] showed that the higher water table during these months creates the necessary oxic/anoxic conditions that, combined with carbon-rich soils enhanced by vegetated buffer strips, prevents nitrates from leaching into streams through the process of denitrification. Buffer design determines the rate at which vegetation retains nitrates and enhances denitrification.

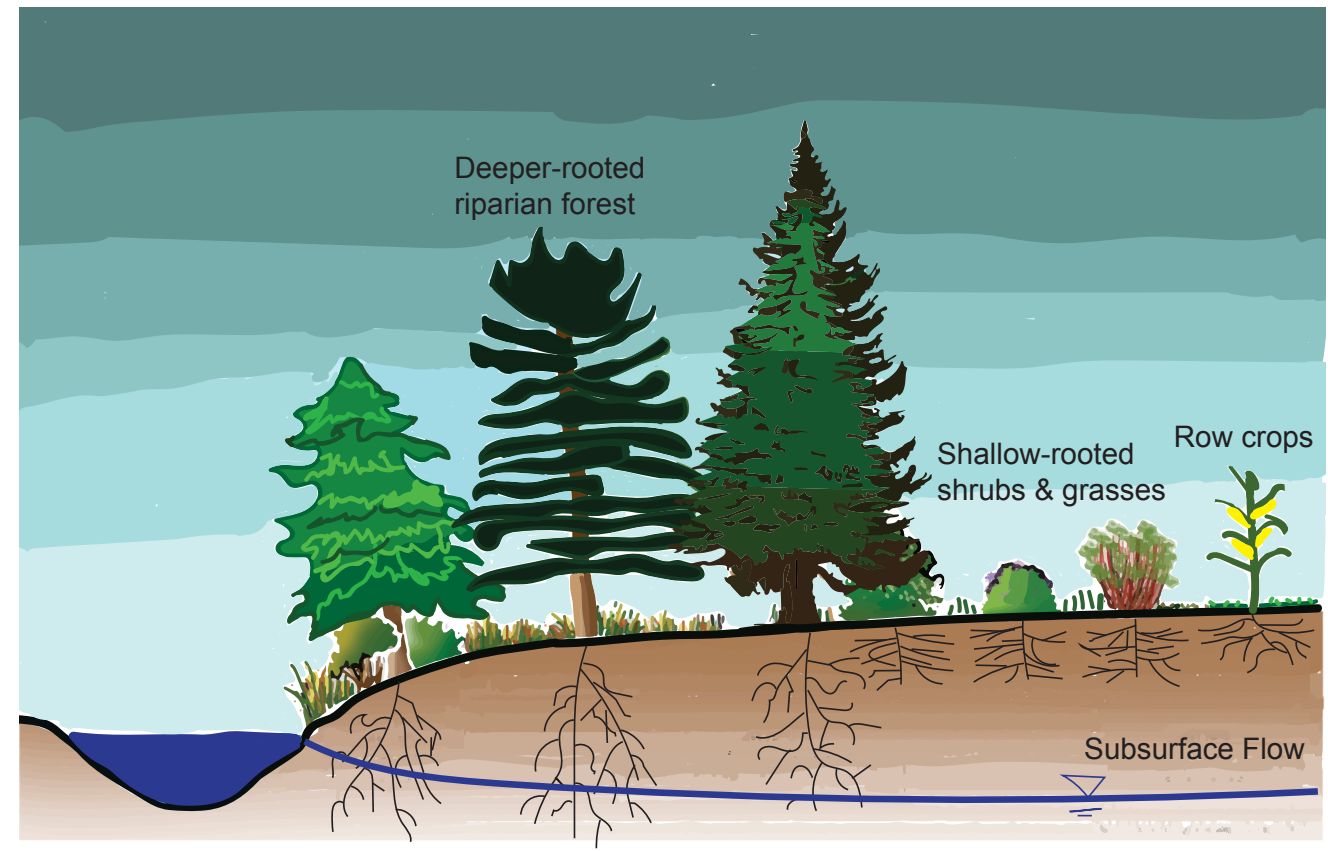

Figure 2. Multi-species riparian buffers include trees, shrubs, and prairie grasses. Grasses attenuate surface runoff and filter out contaminants, while the deeper roots of the shrubs and trees uptake nutrients from groundwater levels.

Buffer strips are also designed to take up phosphorus. Phosphorus $(\mathrm{P})$ is another contributor to eutrophic conditions that lead to hypoxia. P losses occur as particulates attached to soil sediments from field runoff and streambank erosion [46,47]. Soluble P can also leach into groundwater [48]. 
Buffers prevent $\mathrm{P}$ losses by attenuating and infiltrating runoff, at which point particulate $\mathrm{P}$ is converted into biologically active $\mathrm{P}$ and is made available to plants and microorganisms [49]. In fact, the same conditions that are preferred for denitrification facilitate the process of converting particulate $\mathrm{P}$ to biologically active $\mathrm{P}$ [50]. Riparian buffers present a potential solution to $\mathrm{P}$ pollution, but every ditch and stream in agricultural watersheds cannot be lined with buffer strips. Terrain analyses are required to prioritize the location of buffer construction.

In the Midwest, tile drainage exacerbates the problem of nutrient-laden water. Tile drains are located at some distance beneath the surface of a field and lower the water table by conveying excess water away from the field. However, after fertilizers are added to the soil and inorganic nitrogen undergoes nitrification, the resulting nitrates leach into groundwater and are transported via tile drains to surface waters. Tile drains contribute to water pollution, but solutions such as diverting flow to a riparian buffer can help decrease the amount of nutrients leaving fields [51,52]. The 1992 National Resources Inventory database is the most recent and comprehensive report of tile drainage use at the U.S. county level [53], and for the 17 counties comprising the RRW, on average 51 percent of the land utilizes tile drainage [54]. It is difficult to assess the extent of tile drainage in the region, so the results of terrain analyses must be carefully inspected before deciding where riparian buffers are constructed.

Considering the plentiful benefits, the use of buffers is a viable option to manage nitrate levels throughout the United States. A buffer's ability to uptake nutrients and protect water quality is dependent on its location within a watershed. Slope and soil conditions that lead to higher runoff and sediment generation represent better locations for buffers; these locations are typically alongside lower-order streams. Correll [29] found that most of the water moving into receiving water bodies enters through first- and second-order streams. Tomer et al. [28] further show that buffers function better by treating overland runoff and shallow groundwater along first- and second-order streams. These streams are often the most ideal for targeting water quality goals, and we aim to verify this finding by analyzing first- and second-order streams in the RRW.

\subsection{The Principles of Water Quality Trading}

Water quality trading (WQT) represents an opportunity for municipalities, wastewater utilities, and other regulated dischargers to achieve regulatory water quality goals while allowing for flexibility in the level of technology employed. The principles of WQT are similar to those of cap-and-trade pollution mitigation approaches, where discharging entities can install pollution control technologies or purchase discharge credits sold in a watershed market system. In a WQT market, a permitted point source facility would pay for water quality improvements at a nonpoint source, and those water quality improvements are quantified and verified as credits [55]. The U.S. Environmental Protection Agency (EPA) states that WQT is "an option for compliance with a water quality based effluent limitation in a NPDES permit" [56]. Regulated dischargers, most notably industrial and municipal wastewater treatment plants (WWTPs), need to meet water quality standards pertaining to the waterbody to which they discharge effluent. Total maximum daily loads (TMDLs) are assigned if a given waterbody continually fails to meet water quality standards. It can be difficult for WWTPs to meet TMDLs if agricultural runoff is a large contributor to the water quality problem. WQT, then, enables regulated dischargers to purchase agricultural nonpoint source credits. These agricultural nonpoint source credits often lead to the adoption of best management practices (BMPs) on agricultural lands, such as cover crops, reduced tillage, and riparian buffers. Conceptually, regulated dischargers should be willing to purchase agricultural nonpoint source credits if the cost of implementing BMPs is less than treating the water on-site. Additionally, agricultural operators should be willing to sell credits if the price the regulated dischargers are willing to pay is greater than the credit production costs. Credit production costs include any verification costs, as well as BMP implementation costs [57]. However, it is important to engage agricultural operators throughout the process concerning their positions on such environmental policies [58]. WQT has been cost-effective for WWTPs in agricultural watersheds [59], 
including the Chesapeake Bay Watershed [60-62]. WQT programs often focus on eutrophication issues associated with nutrients, specifically nitrogen and phosphorus [63,64].

Using the WWTP as a precedent, we use the same WQT concepts to analyze the possibility of DMWW (a drinking water utility) "purchasing" agricultural nonpoint source credits by sponsoring the installation of riparian buffers to clean their drinking water source. That is, we propose that Des Moines residents, through DMWW, pay for buffer installations in appropriate locations upstream with the purpose of reducing the cost of treating drinking water downstream. The subjects involved in the WQT program are the farmers, the intermediary local agents, and Des Moines Water Works. The RRW is vastly agricultural in nature, and thus we do not simultaneously include any industry or WWTP effluent in our analysis. There is a similar precedent in expanding the meaning of WQT through water quantity trading. Interbasin water transfers have occurred frequently throughout the history of the arid southwestern United States $[65,66]$. To our knowledge, drinking water utilities have not previously utilized the ideas behind WQT to reduce the cost of removing nutrients from water. However, urban residents (through a drinking water utility) might encourage such a solution to reducing nutrient pollution in a river/lake/estuary, as their drinking water source. Although the current relationship between DMWW and upstream agricultural operators is most likely strained, we see potential for cooperation moving forward, especially through enrolling trusted local agents to act as intermediaries between the two parties. We explore the economic feasibility of such an approach in the RRW.

\section{Materials and Methods}

\subsection{Terrain Analysis}

We used terrain analysis techniques put forth by Moore et al. [67] to determine factors such as upslope contributing area, slope, and catchment area that indicate portions of a watershed featuring water accumulation. Analysis of the RRW relies on two factors: slope ( $\beta$, in degrees) and specific catchment area $\left(\mathrm{A}_{s}\right.$, units of $\left.\mathrm{m}^{2} \mathrm{~m}^{-1}\right)$. Slope determines the stream network and subbasins within the RRW, and slope also affects whether a location is fitting to readily remove nitrates from surface runoff or shallow groundwater flow. The specific catchment area is the upslope area that can potentially contribute surface runoff to a grid-cell location per width of flow. Calculating $\mathrm{A}_{s}$ for a raster of topography requires knowledge of the overland flow direction between adjacent cells. Thus, we employed the D- $\infty$ method put forth by Tarboton [68] using software published by D.G. Tarboton [69]. Rather than the typical eight-direction model, the D- $\infty$ method proportions flow as an angle in radians between 0 and $2 \pi$ based on the steepest descent among eight triangular facets formed in a $3 \times 3$ cell block, with the cell of interest in the center (see Tarboton [68] for details).

After calculating $\beta$ and $\mathrm{A}_{s}$, compound hydrologic indices can be calculated to identify priority areas within the RRW. The topographic wetness index (TWI) is defined in Equation (1), and is the compound hydrologic index of interest.

$$
T W I=\ln \left(A_{s} / \tan \beta\right)
$$

We used TWI to demarcate areas most prone to soil saturation during precipitation events. The $\tan \beta$ changed slope from degrees to more topographically useful units of rise over run $(\mathrm{m} / \mathrm{m})$. The natural $\log$ was used because the ratio $\left(\mathrm{A}_{s} / \tan \beta\right)$ spans many orders of magnitude over various landscapes. Areas with a large TWI are better situated for riparian buffers to remove nitrates. Specifically, flat areas with large upslope contributing areas potentially enable buffers to uptake nitrates from shallow groundwater flow and filter surface runoff. Flat areas at the bottom of hillslopes present opportunities for buffers to filter surface runoff, and flat riparian areas often feature shallow groundwater flow. Permanent vegetation can benefit water quality in all of these potential situations. Typically, riparian forest buffers function well for removing nutrients from shallow groundwater flow, while grass strips effectively filter contaminants from surface runoff $[70,71]$. Similar terrain 
analyses have been applied to determine priority stream reaches [72] and riparian zones for field-level planning [73].

Raster datasets of the RRW were retrieved from the National Map. The National Map [74] is a comprehensive bare earth elevation dataset of North America at a 30-meter scale and provides freely available digital elevation models (DEMs). DEMs for the area surrounding the RRW were collected and clipped to the RRW boundaries using watershed delineations found through the National Hydrography Dataset. Two eight-digit Hydrologic Unit Code regions comprise the RRW: the North Raccoon (07100006) and the South Raccoon (07100007).

\subsection{Buffer Design and Cost Analysis}

A sustainable approach to nitrate pollution throughout the RRW takes into consideration the economic costs alongside the environmental benefits. We performed a cost analysis for the distributed approach of agricultural green infrastructure. Equation (2) presents the total cost $\left(C_{T}\right)$ and includes vegetation planting $(V)$, crop opportunity costs $(O)$, maintenance/labor costs $(M L)$, and importantly, transaction costs $(T)$ :

$$
C_{T}=V+M L+O+T .
$$

We first present our buffer design, summarized in Figure 3, as the design determines vegetation costs. Figure 3 illustrates what we call a "buffer unit", which comprises a $20 \mathrm{~m} \times 2 \mathrm{~m}$ area of buffer. There are two species of trees (Jack pine, Pinus banksiana, and eastern red cedar, Juniperus virginiana), two species of bushes (redosier dogwood, Cornus stolonifera, and ninebark, Physocarpus opulifolius), and one species of tall prairie grass (switchgrass, Panicum virgatum). All are native to Iowa, and the tree/shrub saplings can be purchased through the Iowa Department of Natural Resources state forest nursery [75]. We chose Jack pine and eastern red cedar for tree species because both are evergreens and both grow at a rapid pace in full sun. Evergreen trees are preferable over deciduous trees because of the potential for deciduous trees to eventually contribute to water pollution after litterfall [76]. We chose redosier dogwood and ninebark because of their rapid growth rate and ability to grow in full sun. Buffer width is significant, as it determines nitrate removal efficiency. Based on a meta-analysis of riparian buffer studies [77], we chose a 20-m-wide buffer system. A 20-m-wide multi-species riparian buffer can be expected to remove about 75 percent of nitrates coming off agricultural fields [77]. Nitrate levels as high as $30.5 \mathrm{mg} / \mathrm{L}$ have been recorded at USGS Gage 05482500, North Raccoon River near Jefferson, Iowa. Even at such high levels, assuming a fully effective riparian buffer, nitrate levels would be reduced to below the $10 \mathrm{mg} / \mathrm{L}$ federal drinking water limit set by the EPA [78]. Using a 20-m-wide buffer balances the tradeoff between nitrate removal and total cost.

Net present vegetation costs were calculated from six years of planting data, discounted at a rate of 5 percent. We assumed a 60-70 percent tree/shrub survival rate from the first year to the second and third years, a conservative approach (e.g., [79]). The cost of trees and shrubs were sourced from the Iowa Department of Natural Resources seedling catalog. Trees require a shelter and accompanying stake upon planting, and thus we included these costs based on a sample manufacturer, Forestry Suppliers [80]. Switchgrass costs were based on the cost of seed. Equation (3) presents the cost of one hectare of switchgrass, where "PLS" indicates "pure live seed", the term used to describe switchgrass seed. The cost of switchgrass seed came from the Osenbaugh Prairie Seed Farms in Lucas, Iowa [81], and the amount of seed came from a study published by West and Kincer [82] which determined that $6.72 \mathrm{~kg} \mathrm{PLS} \mathrm{ha}^{-1}$ grew a sufficient amount of switchgrass. Vegetation costs are presented in Table 2.

$$
\frac{\$ 7.50}{\operatorname{PLS~lb}} \cdot \frac{\mathrm{lb}}{0.454 \mathrm{~kg}} \cdot \frac{6.72 \mathrm{~kg} \text { PLS }}{1 \text { hectare }}=\$ 111 / \mathrm{ha}
$$


$\longrightarrow$ Direction of surface runoff/groundwater flow

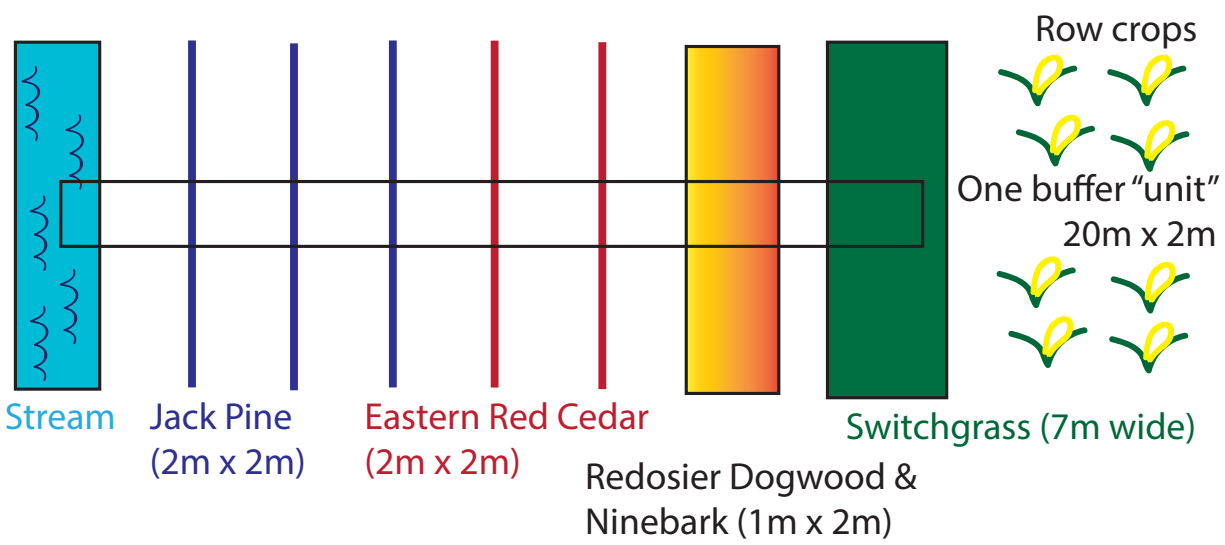

Figure 3. Multi-species riparian buffer design with spacing dimensions. One "unit" represents three parallel Jack pines, two parallel eastern red cedars, one redosier dogwood bush, one ninebark bush, and a $7 \mathrm{~m} \times 2 \mathrm{~m}$ plot of switchgrass.

Table 2. Vegetation material costs per hectare (per acre) for the six-year cost period. Ranges represent the amount of replanting necessary from year to year.

\begin{tabular}{cccccc}
\hline Item & Quantity & Initial Cost & $\begin{array}{l}\text { Replanting, } \\
\text { Years 2 and 3 }\end{array}$ & $\begin{array}{l}\text { Tree Shelter, } \\
\text { 6 years }\end{array}$ & $\begin{array}{l}\text { Net Present } \\
\text { Cost, 6 years }\end{array}$ \\
\hline Eastern Red Cedar & 500 & $\$ 500$ & $\$ 150-\$ 200$ & $\$ 1129-\$ 1270$ & $\$ 1908-\$ 2142$ \\
& $(202)$ & $(\$ 202)$ & $(\$ 60-\$ 80)$ & $(\$ 456-\$ 512)$ & $(\$ 769-\$ 863)$ \\
Jack Pine & 750 & $\$ 413$ & $\$ 124-\$ 165$ & $\$ 1694-\$ 1906$ & $\$ 2336-\$ 2625$ \\
& $(303)$ & $(\$ 167)$ & $(\$ 50-\$ 67)$ & $(\$ 683-\$ 769)$ & $(\$ 942-\$ 1060)$ \\
Redosier Dogwood & 250 & $\$ 225$ & $\$ 68-\$ 90$ & $\mathrm{~N} / \mathrm{A}$ & $\$ 351-\$ 392$ \\
& $(101)$ & $(\$ 91)$ & $(\$ 27-\$ 36)$ & $(\mathrm{N} / \mathrm{A})$ & $(\$ 141-\$ 158)$ \\
Ninebark & 250 & $\$ 225$ & $\$ 68-\$ 90$ & $\mathrm{~N} / \mathrm{A}$ & $\$ 351-\$ 392$ \\
& $(101)$ & $(\$ 91)$ & $(\$ 27-\$ 36)$ & $(\mathrm{N} / \mathrm{A})$ & $(\$ 141-\$ 158)$ \\
Switchgrass & 1 & $\$ 111$ & $\mathrm{~N} / \mathrm{A}$ & $\mathrm{N} / \mathrm{A}$ & $\$ 111$ \\
& $(1)$ & $(\$ 49)$ & $(\mathrm{N} / \mathrm{A})$ & $(\mathrm{N} / \mathrm{A})$ & $(\$ 49)$ \\
\hline
\end{tabular}

Maintenance and labor costs cover several activities and materials, including herbicide treatment and mowing between rows of vegetation. Mowing is necessary to reduce competition between inevitably-occurring weeds and the newly planted trees and bushes. Herbicides are also recommended to reduce such competition. These two maintenance techniques are recommended by the Iowa State University (ISU) Extension with corresponding maintenance cost data [83]. Accompanying such maintenance costs are the labor costs associated with preparing the land for buffer placement, planting vegetation, and maintaining the buffers. According to the Bureau of Labor and Statistics 2016 data for the state of Iowa, forest and conservation workers (occupation code 45-4001) earned a mean hourly salary of $\$ 15.86$. Such land preparation costs terminate after the third year in the six-year analysis period. Using the ISU Extension labor data to estimate the time required for various activities, we calculated labor costs per hectare of buffer installation (Table 3).

We labeled the third category included in our riparian buffer cost analysis "opportunity costs". Payments to farmers for use of their land as well as payments in recompense for lost crop growth (and thus, lost revenue) were included in opportunity costs. There are six counties that make up the vast majority of the RRW: Dallas, Guthrie, Greene, Carroll, Sac, and Calhoun. We used yield, hectares planted, and market price data published by the USDA National Agriculture Statistics Service for the year 2016 to calculate the cost of taking corn/soybean crops out of production (Table 4). Upper and lower bounds represent the amount of land assumed to viably support crop growth. The conservative 
upper bound assumes all buffer land that otherwise would have supported crops, and the realistic approach assumes that 75 percent of buffer land would have supported crops (lower bound). Buffers would be placed on already marginal land, and thus, in practice, DMWW and the farmers could likely compromise on a payment between the two bounds. Final opportunity costs were an average between the six counties, calculated as net present cost with decreasing payments to farmers in the latter four years of the six-year analysis. WQT programs sometimes quantify the exact cost of credits (i.e., dollars per pound of nutrient). However, such a quantification is beyond the scope of our analysis and would not be transferable to other watersheds, as was our motivation for this study. Opportunity costs represent the largest portion of total costs for the riparian buffer scenario because farmers are being asked to take land out of production, representing both an economic and cultural cost.

Table 3. Maintenance activities and their associated labor costs for buffer installation, using the labor rate from the Iowa State University Extension, for an entire year. Ranges represent the amount of labor required based on replanting rates per hectare (per acre).

\begin{tabular}{ccc}
\hline Maintenance activity & \multicolumn{3}{c}{ Value per hectare (per acre) } \\
\hline Site Prep $(\mathrm{h} / \mathrm{ha})$ & 5 & $(2)$ \\
Vegetation Planting $(\mathrm{h} / \mathrm{ha})$ & $40-50$ & $(16-20)$ \\
Site Maintenance $(\mathrm{h} / \mathrm{ha})$ & $3.75-7.5$ & $(1.5-3)$ \\
Mowing $(\mathrm{h} / \mathrm{ha})$ & 3.75 & $(1.5)$ \\
Herbicide Costs $(\$ / \mathrm{ha})$ & $\$ 39-\$ 42$ & $(\$ 15-\$ 17)$ \\
Labor Rate $(\$ / \mathrm{h})$ & \multicolumn{3}{c}{$\$ 15.86$} \\
\hline Total Labor $\mathbf{( \$ \mathbf { h a } )}$ & $\mathbf{\$ 8 7 1 - \$ 1 0 9 3}$ & $\mathbf{( \$ 3 4 8 - \$ 4 3 7 )}$ \\
\hline
\end{tabular}

Table 4. Land lease and opportunity costs per hectare (per acre) for RRW counties. Values are based on 2016 National Agriculture Statistics Service data, in addition to the land rent values.

\begin{tabular}{ccccccc}
\hline County & $\begin{array}{c}\text { Corn } \\
\text { ha (acre) }\end{array}$ & $\begin{array}{c}\text { Corn Opportunity } \\
\text { Cost }\end{array}$ & $\begin{array}{c}\text { Soybean } \\
\text { ha (acre) }\end{array}$ & $\begin{array}{c}\text { Soybean Opportunity } \\
\text { Cost }\end{array}$ & $\begin{array}{c}\mathbf{2 0 1 7} \\
\text { Rent }\end{array}$ & $\begin{array}{c}\text { Total Opportunity } \\
\text { Cost } \mathbf{\$} / \mathbf{y r})\end{array}$ \\
\hline Dallas & 58,881 & $\$ 1825-\$ 2247$ & 39,416 & $\$ 1586-\$ 1929$ & $\$ 558$ & $\mathbf{\$ 1 7 2 9 - \$ 2 1 2 0}$ \\
& $(145,500)$ & $(\$ 739-\$ 909)$ & $(97,400)$ & $(\$ 642-\$ 781)$ & $(\$ 226)$ & $\mathbf{( \$ 7 0 0 - \$ 8 5 8 )}$ \\
Guthrie & 44,919 & $\$ 1716-\$ 2126$ & 36,381 & $\$ 1515-\$ 1857$ & $\$ 487$ & $\mathbf{\$ 1 6 2 6 - \$ 2 0 1 8}$ \\
& $(111,000)$ & $(\$ 694-\$ 860)$ & $(89,900)$ & $(\$ 613-\$ 752)$ & $(\$ 197)$ & $\mathbf{( \$ 6 5 8 - \$ 8 1 7 )}$ \\
Greene & 72,842 & $\$ 1840-\$ 2266$ & 47,347 & $\$ 1676-\$ 2048$ & $\$ 561$ & $\mathbf{\$ 1 7 7 5 - \$ 2 1 7 9}$ \\
& $(180,000)$ & $(\$ 745-\$ 917)$ & $(117,000)$ & $(\$ 678-\$ 829)$ & $(\$ 227)$ & $\mathbf{( \$ 7 1 8 - \$ 8 8 2 )}$ \\
Carroll & 79,115 & $\$ 1873-\$ 2293$ & 43503 & $\$ 1641-\$ 1983$ & $\$ 613$ & $\mathbf{\$ 1 7 9 1 - \$ 2 1 6 9}$ \\
& $(195,500)$ & $(\$ 758-\$ 928)$ & $(107,500)$ & $(\$ 664-\$ 803)$ & $(\$ 248)$ & $\mathbf{( \$ 7 2 5 - \$ 8 7 8 )}$ \\
Sac & 68,795 & $\$ 1932-\$ 2374$ & 52,001 & $\$ 1718-\$ 2090$ & $\$ 603$ & $\mathbf{\$ 1 8 4 0 - \$ 2 2 6 0}$ \\
& $(170,000)$ & $(\$ 782-\$ 961)$ & $(128,500)$ & $(\$ 695-\$ 846)$ & $(\$ 244)$ & $\mathbf{( \$ 7 4 4 - \$ 9 1 5 )}$ \\
Calhoun & 74,461 & $\$ 1866-\$ 2294$ & 51,596 & $\$ 1678-\$ 2044$ & $\$ 581$ & $\mathbf{\$ 1 7 8 9 - \$ 2 1 9 4}$ \\
& $(184,000)$ & $(\$ 755-\$ 928)$ & $(127,500)$ & $(\$ 679-\$ 827)$ & $(\$ 235)$ & $\mathbf{( \$ 7 2 4 - \$ 8 8 8 )}$ \\
\hline
\end{tabular}

Lastly, we analyzed the transaction costs associated with a widespread installation of riparian buffers on farmers' private land. Such costs include, but are not limited to, the person-hours required to recruit farmers, educate them and other stakeholders concerning the details of such a riparian buffer WQT program, and continue to act as an intermediary between DMWW and the farmers when trades are completed. The significant amount of time and energy required to facilitate trades is widely cited as a reason for the lack of robustness in WQT programs [84-86]. WQT literature increasingly points to the importance of social embeddedness (i.e., trust) in the success of WQT programs [87-89]. Local actors, often staff at Soil and Water Conservation Districts (SWCDs) or Extension offices, are a highly valued element in successful WQT programs. Theoretically, a free and open market for WQT would logically lead to as many trades as possible taking place between farmers and polluters, especially when benefits are made explicit. However, Breetz et al. [90] state that "A strong pride in private property, a history of tensions with industrial actors, or a desire to be recognized for land stewardship are just a 
few of the attitudes and values that can establish powerful norms of behavior discouraging trades". Mariola [91] performed a review of WQT programs throughout the United States and Canada and determined that having a trusted local agent whose main responsibility was to visit farmers and talk about the WQT program is crucial to success. Working with trusted local intermediaries facilitates a more rapid and increased flow of information and reassures farmers that they can trust the information they are receiving [90].

We incorporated the costs of staffing local intermediaries into our analysis as transaction costs. Because of the significance of having someone whose sole responsibility is to discuss potential WQT programs with farmers, we estimated costs based on salary for one staff member in each of the six county SWCDs comprising the RRW for dedicated work with farmers and DMWW. According to the Bureau of Labor Statistics, the 2017 mean annual wage of conservation scientists (occupation code $19-1031$ ) was $\$ 55,240$. Thus, staffing someone in each of the six counties to work with this potential WQT program would cost $\$ 331,440$ in the first year, and $\$ 1,852,000$ in the six-year study period (including 2 percent salary increases each year to cover inflation costs). We added these transaction costs as a crucial element of the potential success of the riparian buffer installation scenario.

In their description of WQT, the EPA sets forth that credits are "a unit of pollutant reduction usually measured in pounds equivalent". They do not describe how such a credit is priced-this phenomenon is left up to a free, efficient market, which we assume is feasible in Iowa. That is, related costs to WQT are left to negotiation between an administrator (in this case, DMWW) and agricultural operators [92]. Units of trade and timing of credits, along with their price, are beyond the scope of this analysis.

\subsection{Nitrate Removal Facility Costs}

In our second proposed solution to the nitrate management issue, we gathered the costs required for DMWW to operate its nitrate removal facility as well as construct a new treatment facility altogether. A recently-passed Five-Year Capital Plan [93,94] includes $\$ 70$ million earmarked specifically for nitrate removal measures, with an additional $\$ 10$ million in the sixth year. We calculated the net present cost of such expenditures using a 5 percent discount rate, similar to the distributed green approach. DMWW CEO Bill Stowe has stated that the utility company prefers to continually repair and maintain the current nitrate removal facility over constructing a new one [94]. A new facility could cost up to $\$ 184$ million [19], a tremendous burden on Des Moines residents. This worst-case scenario is the cost we considered for Scenario S2.

\section{Results}

Terrain analyses confirmed that first- and second-order streams are most suitable for buffer placement within the RRW. Figure 4 presents TWIs for the extent of the RRW, and Table 5 gives the results for each stream order. We performed a Student's $t$-test to determine which stream orders were significantly different from one another, and the results indicate that first-order streams had significantly $(p<0.05)$ higher TWI values compared to higher-order streams. This finding agrees with other studies analyzing optimal buffer placement $[29,95]$. Consequently, we focused on first-order streams in the RRW as prime locations for buffer installation under the agricultural green infrastructure approach.

Table 6 summarizes the total costs per hectare of riparian buffer installation, and Table 7 presents overall costs for each of the scenarios. Business as usual is not feasible because the current insufficient nitrate removal facility will eventually become defunct without renovation or replacement. Not meeting drinking water nitrate standards is not allowed by law. Final costs for the distributed green approach were estimated at between $\$ 155-\$ 185$ million. Again, we are proposing a partnership between DMWW and upstream agricultural operators, based off the principles of WQT, wherein Des Moines residents are paying for these costs over the period of time required to finance the buffer installation project. These numbers represent a conservative approach in which agricultural green infrastructure in the form of riparian buffers are installed along nearly every first-order stream. In total, 
there are about 9700 hectares (24,000 acres) of riparian buffer, and the upper and lower bounds represent the amount of replanting required (and accompanying labor/maintenance costs). A new nitrate removal facility in the centralized gray approach could cost $\$ 184$ million. There is already $\$ 72$ million earmarked for updates and maintenance of the nitrate removal facility over the next six years [93]. DMWW already anticipates passing these costs to ratepayers, and so we do not include this number in Table 7. The $\$ 184$ million figure is the estimated cost of a completely new nitrate removal facility [19]. Constructing a new facility is the worst-case scenario economically, as DMWW would require financing, the cost of which would eventually be transferred to ratepayers.

Table 5. Topographic wetness index (TWI) results for the Raccoon River Watershed indicate that first-order streams are most suitable for buffer location based on topography.

\begin{tabular}{ccccc}
\hline Stream Order & Maximum & Range & Mean & Standard Deviation \\
\hline 1 & 17.9 & 16.1 & 5.41 & 1.93 \\
2 & 16.3 & 14.8 & 5.37 & 2.00 \\
3 & 17.5 & 15.6 & 5.27 & 1.98 \\
4 & 19.2 & 17.5 & 5.08 & 1.92 \\
5 & 20.4 & 18.8 & 4.94 & 1.82 \\
6 & 20.8 & 19.1 & 4.69 & 1.72 \\
7 & 22.7 & 21.2 & 4.71 & 1.67 \\
8 & 23.2 & 21.6 & 4.59 & 1.71 \\
\hline
\end{tabular}

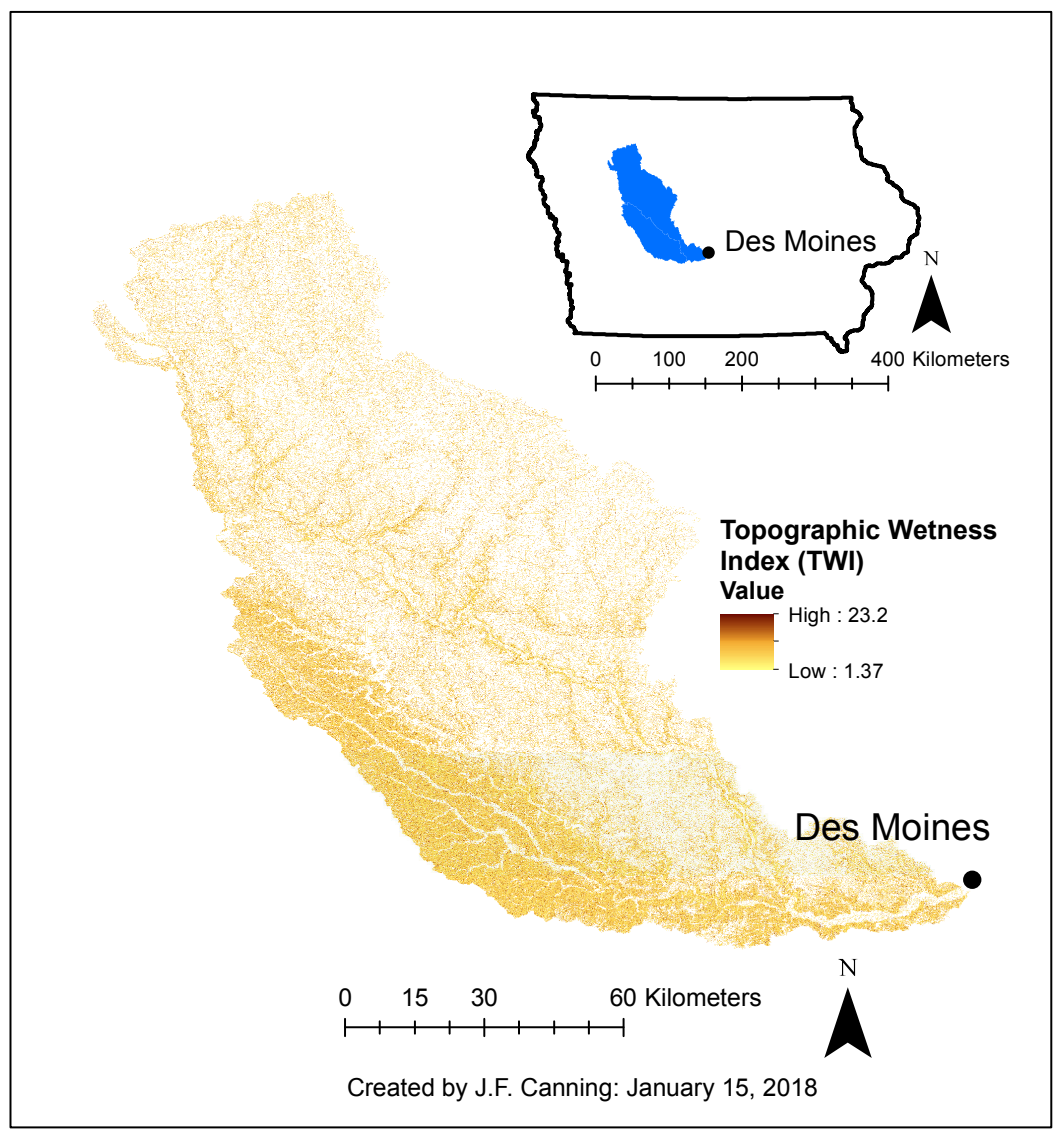

Figure 4. The resulting TWI map. A higher TWI represents land more suitable for riparian buffer placement. 
Table 6. Total net present cost of the agricultural green infrastructure approach over the six-year period per hectare (per acre). Transaction costs are for the entire program, not per hectare.

\begin{tabular}{cc}
\hline Cost component & Cost per hectare (per acre) \\
\hline Vegetation Costs & $\$ 5071-\$ 5678$ \\
& $(\$ 2057-\$ 2302)$ \\
Labor Costs & $\$ 2880-\$ 3514$ \\
& $(\$ 1152-\$ 1468)$ \\
Opportunity Costs & $\$ 7923-\$ 9717$ \\
& $(\$ 3206-\$ 3932)$ \\
\hline Net Present Cost & $\$ 15,874-\$ 18,909$ \\
& $\mathbf{( \$ 6 4 1 5 - \$ 7 7 0 3 )}$ \\
\hline Transaction Costs & $\$ 1,852,000$ \\
\hline
\end{tabular}

Table 7. Scenario analysis results show that water quality trading (WQT) can be a cost-competitive approach to nitrate control through agricultural green infrastructure.

\begin{tabular}{ccc}
\hline Scenario & Description & Cost (\$million) \\
\hline S1 & WQT Riparian Buffers & $\$ 155-\$ 185$ \\
S2 & Nitrate Removal Facility & $\$ 184$ \\
\hline
\end{tabular}

\section{Discussion}

\subsection{Policy Implications - Current Policy and Shortcomings}

Terrain analysis results can lead to improved water quality if riparian buffers are employed throughout the RRW. However, implementing buffers is currently left to farmers and other riparian property owners to do so voluntarily. Buffers are often supported financially and technologically by USDA conservation reserve programs, but there are no regulations requiring farmers to install buffers. Researchers have scrutinized whether voluntary conservation programs have environmental benefits that actually outweigh the cost of taxpayer dollars. Several studies have investigated the cost-benefit relationship of agri-environment programs [96,97]. Claassen et al. [96] found that both the Conservation Reserve Program (CRP) and Environmental Quality Incentive Program (EQIP), two of the USDA's largest conservation programs, have much room for improvement (i.e., the deficit between benefits and costs can be eliminated and then reversed). The authors state that targeting payments toward performance of conservation measures (instead of mere practice) can increase benefits, and costs could be pushed down by encouraging more intense competition for payments [96]. Quantification of benefits is crucial for informing policy, and so studies that detail benefits are important for improving voluntary conservation programs.

Various authors have analyzed whether source water protection is a viable, cost-effective program. In 1986, Shortle and Dunn [98] compared policy measures that could be used to improve water quality conditions hampered by agricultural runoff. The authors found that economic incentives (e.g., a tax on soil loss) placed on farm management practices were the most practical and cost-effective measures that could be implemented. A small portfolio of incremental taxes for certain management practices would encourage farmers to adopt practices that maximize social environmental benefits. Three decades have passed since Shortle and Dunn [98], along with Harrington et al. [99], Gianessi and Peskin [100], and Libby [101], recommended economic incentives to change behaviors and improve the quality of source water rather than voluntary participation.

In 2014, the USDA introduced the Source Water Protection Program (SWPP) with a goal of helping communities, especially rural communities, develop a plan to decrease source water pollution risks. The SWPP does not (1) regulate agricultural runoff; (2) require that farmers comply with runoff standards; or (3) levy taxes on farmers for creating polluted waters. The Clean Water Act 
prevents SWPP, CRP, EQIP, and other programs from enforcing any sort of regulation restricting the runoff flowing off agricultural fields (as nonpoint sources), subsequently affecting rural communities. Despite long-standing research recommendations to create economic incentives to deter source water pollution, policymakers have been unable to improve upon voluntary conservation measures. Source water pollution became a serious issue for the city of Des Moines, Iowa, USA, and led to potential changes in how agricultural runoff might be addressed.

\subsection{Comparing the Gray and Green Approaches}

The RRW has an increasing water quality problem. DMWW unsuccessfully attempted to force farmers to pay to treat the water flowing off their fields, and the paltry effectiveness of USDA conservation programs indicates that novel physical and policy solutions are required. A distributed, green approach — widespread riparian buffer installation—would indeed cost DMWW (i.e., ratepayers) tens of millions of dollars more than continuing to maintain the nitrate removal facility. However, there are many benefits to the distributed green approach compared to the centralized gray approach. Construction and maintenance of the buffer network would require hundreds of hours of human labor, giving people living-wage and accessible employment. Such a social co-benefit pointedly addresses the triple-bottom line assessment of sustainability. Constructing a new nitrate removal facility would also require increased engineering and manufacturing jobs, an unquantified benefit of that scenario. However, such jobs might not be as accessible to unemployed/underemployed lower-skilled laborers seeking work. Further benefits include carbon sequestration [102] and wildlife habitat due to the vegetation [103]. Once established, the trees would provide cooling effects throughout the stream network, providing further water quality benefits [104]. Quantification of these indirect benefits is often prone to errors and bias, and thus we do not quantify these benefits in our present analysis. However, the implication is that buffer installation offers more benefits than solely the reduction of nitrates in drinking water. Table 8 summarizes the indirect, non-quantified benefits of Scenarios S1 and S2. Economically and socially, although buffer installation costs more than maintaining the present nitrate removal facility and could cost about the same as a new facility, the former offers various additional environmental and social benefits.

Table 8. The agricultural green infrastructure (S1) and centralized gray (S2) approaches have different indirect, non-quantified benefits.

\begin{tabular}{cc}
\hline Agricultural Green Infrastructure & New Centralized Nitrate Removal Facility \\
\hline Carbon sequestration & White-collar design and engineering jobs \\
Wildlife habitat & Facility maintenance jobs \\
In-stream water quality improvement & Potential for nutrient recovery \\
Blue-collar conservation jobs & \\
Address rural-urban divide & \\
Reduced energy consumption treating drinking water & \\
\hline
\end{tabular}

There are some complexities associated with a widespread riparian buffer program. For example, hiring the laborers to maintain the buffer systems does entail gaining access to private property. Additionally, the participation of farmers could be overestimated-if only half of the targeted farmers were willing to participate, the reduction in nitrate levels might not be enough to prevent the necessity of a new nitrate removal facility. However, representatives from SWCDs or local Extensions could engage and educate farmers on these potential issues. Such complexities certainly could exist, but are outside the scope of our analysis.

Agricultural green infrastructure is indeed more expensive than maintaining and updating the current nitrate removal facility, but building out riparian buffers could avoid the extravagant costs associated with building a new nitrate removal facility. DMWW has already committed $\$ 72$ million to maintaining the current facilities. At some point, increased investment will be necessary to at least 
renovate the facility, especially if nitrate levels continue to rise. Building a new facility might not be necessary in the near future given such investment in renovation. However, the facility cannot endure into perpetuity. A new facility will most likely be necessary at some point, at which time costs will almost certainly be higher. Furthermore, maintaining and/or building the current/new facility will accrue limited environmental or social benefits. It might be more expensive at the current moment to install widespread riparian buffers, but such a project helps avoid the need to invest heavily in a new facility in the medium- to long-term future.

Both the centralized gray approach and the distributed green approach fulfill the requirement that DMWW reduce nitrate levels below the federal standard. However, the distributed green approach might also help to alleviate an issue that appeared during the DMWW litigation: the rural-urban disconnect. The U.S. Water Alliance recently published seven ideas to solve the U.S. water crises, and at the top of the list is accelerating "agriculture-utility partnerships to improve water quality" [105]. Water quality trading through the construction of riparian buffers allows the wealthy and resource-intensive urban residents to sponsor projects in rural communities that provide clean drinking water. Rural residents are fairly compensated for use of their land, and there are other environmental and social/economic benefits for both communities. WQT enables a compromise that offers benefits to both urban and rural residents-benefits that the lawsuit could not offer to both parties.

Additional considerations beyond our analysis include determining where tile drainage is used throughout the RRW and incorporating such drainage into the multi-species riparian buffer design. Buffers do not reduce nutrient pollution if tile drains are installed; however, there are potential solutions available. One such suggested solution is the use of constructed wetlands at certain intervals along a field with tile drainage $[106,107]$. Constructed wetlands are similar to riparian buffers in that they feature vegetation that will uptake nutrients running off agricultural fields. Their defining feature, however, is the anoxic conditions they create, allowing for denitrification to occur. Constructed wetlands are placed between the tile drain outlet and the recipient stream, thus acting to purify surface runoff and groundwater before it enters the stream. To reduce the problem of flow bypassing riparian buffers, Schultz et al. [79] recommended that one hectare of wetland be constructed at the field outlet for every 100 hectares of tile-drained agricultural field. Using the distributed green approach in the RRW would require field-level analysis to determine whether tile drainage is present and, if so, where to install constructed wetlands.

\section{Conclusions}

Nitrates running off agricultural fields from fertilizer inputs are a major water quality issue throughout the Midwestern United States. The Raccoon River Watershed (RRW) upstream of Des Moines, Iowa, USA has some of the highest nitrate levels in the country, and Des Moines Water Works (DMWW) operates one of the world's largest nitrate removal facilities to reduce levels below the federal drinking water standard. In 2015, DMWW pursued litigation against upstream drainage districts, claiming that agricultural operators should be responsible for the high nitrate levels and treat the water leaving fields through tile drains. DMWW was unsuccessful in its litigation, and the nitrate problem continues to plague Des Moines residents. We analyzed two possible response scenarios to the issue (business as usual is infeasible in the long-term and was thus not considered): (S1) initiating an extensive agricultural green infrastructure project, and (S2) maintaining the current nitrate removal facility and/or building a new facility. The first response is the widespread installation of agricultural green infrastructure in the form of riparian buffers along first-order streams throughout the RRW—-the distributed, green approach. Water quality trading (WQT) encourages utility-agriculture partnerships to improve water quality, extended to apply to drinking water quality at DMWW. This proposition could cost Des Moines residents between $\$ 155$ and $\$ 185$ million, depending on the amount of vegetation required. This investment is admittedly a large sum of money. However, there are additional benefits beyond improved water quality, including increased living-wage jobs and carbon sequestration. Furthermore, the distributed, green approach helps bridge the rural-urban divide by 
providing a means for cooperation between the two parties. The second response includes renovations of the nitrate removal facility and the potential construction of a new facility-the centralized, gray approach. In our analysis, this proposition could cost Des Moines ratepayers $\$ 184$ million, representing a completely new nitrate removal facility. Building a new nitrate removal facility certainly addresses nitrate pollution, but it does not advance cooperation between DMWW and upstream agricultural operators. Ultimately, infrastructure and management approaches are necessary to address water quality challenges, both in the RRW and throughout other agricultural watersheds in the Midwestern United States. Centralized treatment provides residents with clean drinking water, with fewer of the added co-benefits of a distributed, green approach. Agricultural green infrastructure is a potential solution to improving water quality with several co-benefits, and water quality trading approaches can encourage such solutions.

Author Contributions: J.F.C. completed the analysis and wrote the manuscript. A.S.S. supervised the analysis and assisted with writing the manuscript.

Acknowledgments: This work was supported by the Department of Civil and Environmental Engineering at the University of Illinois at Urbana-Champaign. J.F.C. was supported by a CEE Fellowship at the University of Illinois at Urbana-Champaign.

Conflicts of Interest: The authors declare no conflict of interest.

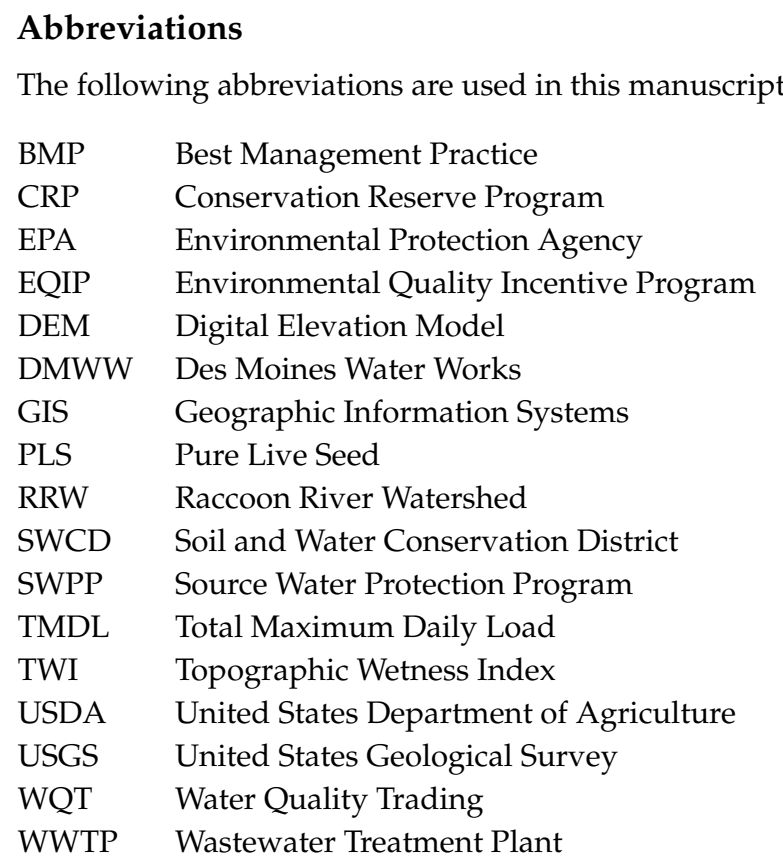

\section{References and Note}

1. Tilman, D.; Balzer, C.; Hill, J.; Befort, B. Global food demand and the sustainable intensification of agriculture. Proc. Natl. Acad. Sci. USA 2011, 108, 20260-20264. [CrossRef] [PubMed]

2. Godfray, H.; Beddington, J.; Crute, I.; Haddad, L.; Lawrence, D.; Muir, J.; Pretty, J.; Robinson, S.; Thomas, S.; Toulmin, C. Food security: The challenge of feeding 9 billion people. Science 2010, 327, 812-818. [CrossRef] [PubMed]

3. Dabrowski, J.; Murray, K.; Ashton, P.; Leaner, J. Agricultural impacts on water quality and implications for virtual water trading decisions. Ecol. Econ. 2009, 68, 1074-1082. [CrossRef]

4. Spahr, N.; Dubrovsky, N.; Gronberg, J.; Franke, O.; Wolock, D. Nitrate Loads and Concentrations in Surface-Water Base Flow and Shallow Groundwater for Selected Basins in the United States, Water Years 1990-2006; U.S. Geological Survey Scientific Investigations Report 2010-5098; U.S. Geological Survey: Reston, VA, USA, 2010. 
5. Powlson, D.; Addiscott, T.; Benjamin, N.; Cassman, K.; de Kok, T.; van Grinsven, H.; L'hirondel, J.; Avery, A.; van Kessel, C. When does nitrate become a risk for humans? J. Environ. Qual. 2008, 37, 291-295. [CrossRef] [PubMed]

6. Greer, F.R.; Shannon, M. Infant methemoglobinemia: The role of dietary nitrate in food and water. Pediatrics 2005, 116, 784-786. [CrossRef] [PubMed]

7. Hamlin, H. Nitrate toxicity in Siberian sturgeon (Acipenser baeri). Aquaculture 2005, 253, 688-693. [CrossRef]

8. Hrubec, T.; Smith, S.; Robertson, J. Nitrate toxicity: A potential problem of recirculating systems. Proc. Aquacult. Eng. Soc. 1996, 1, 41-48.

9. Schram, E.; Roques, J.; Abbink, W.; Yokohama, Y.; Spanings, T.; de vries, P.; Bierman, S.; van de Vis, H.; Flik, G. The impact of elevated water nitrate concentration on physiology, growth and feed intake of African catfish Clarias gariepinus (Burchell 1822). Aquac. Res. 2014, 45, 1499-1511. [CrossRef]

10. Heisler, J.; Glibert, P.M.; Burkholder, J.M.; Anderson, D.M.; Cochlan, W.; Dennison, W.C.; Dortch, Q.; Gobler, C.J.; Heil, C.A.; Humphries, E. Eutrophication and harmful algal blooms: A scientific consensus. Harmful Algae 2008, 8, 3-13. [CrossRef] [PubMed]

11. Turner, R.E.; Rabalais, N.N. 2017 Forecast: Summer Hypoxic Zone Size Northern Gulf of Mexico; Louisiana State University: Baton Rouge, LA, USA, 2017.

12. Louisiana Universities Marine Consortium. What is Hypoxia? 2017. Available online: http:// www.gulfhypoxia.net/Overview / (accessed on 16 May 2018).

13. Carstensen, J.; Andersen, J.H.; Gustafsson, B.G.; Conley, D.J. Deoxygenation of the Baltic Sea during the last century. Proc. Natl. Acad. Sci. USA 2014, 111, 5628-5633. [CrossRef] [PubMed]

14. Louisiana Universities Marine Consortium. Press Release Summary; Rabalais, N.N., Turner, R.E., Eds.; Louisiana Universities Marine Consortium: Chauvin, LA, USA, 2015.

15. Illinois Department of Agriculture; Illinois Environmental Protection Agency; University of Illinois at Urbana-Champaign. Illinois Nutrient Loss Reduction Strategy; Illinois Environmental Protection Agency: Springfield, IL, USA, 2015.

16. Iowa Dept of Agriculture \& Land Stewardship; Iowa Dept of Natural Resources; Iowa State University College of Agriculture and Life Sciences. Iowa Nutrient Reduction Strategy A Science and Technology-Based Framework to Assess and Reduce Nutrients to Iowa Waters and the Gulf of Mexico; Iowa State University: Ames, IA, USA, 2016.

17. Minnesota Pollution Control Agency; Minnesota Dept of Agriculture; Minnesota Board of Water \& Soil Resources; University of Minnesota. The Minnesota Nutrient Reduction Strategy; Minnesota Pollution Control Agency: St. Paul, MN, USA, 2014.

18. Schilling, K.; Zhang, Y. Baseflow contribution to nitrate-nitrogen export from a large, agricultural watershed. J. Hydrol. 2004, 295, 305-316. [CrossRef]

19. Crawford, A.L. Nutrient Pollution and the Gulf of Mexico Dead Zone: Will Des Moines Water Works Be a Turning Point? Tulane Law Rev. 2016, 91, 157.

20. Hatfield, J.; McMullen, L.; Jones, C. Nitrate-nitrogen patterns in the Raccoon River Basin related to agricultural practices. J. Soil Water Conserv. 2009, 64, 190-199. [CrossRef]

21. Howarth, R.W.; Sharpley, A.; Walker, D. Sources of nutrient pollution to coastal waters in the United States: Implications for achieving coastal water quality goals. Estuaries 2002, 25, 656-676. [CrossRef]

22. Ocean Studies Board; National Research Council. Clean Coastal Waters: Understanding and Reducing the Effects Of Nutrient Pollution; National Academies Press: Washington, DC, USA, 2000.

23. Doering, O.; Galloway, J.; Theis, T.; Aneja, V.; Boyer, E.; Cassman, K.; Cowling, E.; Dickerson, R.; Herz, W.; Hey, D.; et al. Reactive Nitrogen in the United States: An Analysis of Inputs, Flows, Consequences, and Management Options; U.S. Environmental Protection Agency: Washington, DC, USA, 2011.

24. Gilliam, J.; Parsons, J.; Mikkelsen, R. Nitrogen dynamics and buffer zones. In Buffer Zones: Their Processes and Potential in Water Protection; Haycock, N.E., Burt, T.P., Goulding, K.W.T., Pinay, G., Eds.; Quest Environmental: Hertfordshire, UK, 1996.

25. Hill, A.R. Nitrate removal in stream riparian zones. J. Environ. Qual. 1996, 25, 743-755. [CrossRef]

26. Lutz, D. Water Quality Studies: Red Rock and Saylorville Reservoirs, Des Moines River, Iowa; Annual Report; Iowa State University, Department of Civil, Construction, and Environmental Engineering, Engineering Research Institute: Ames, IA, USA, 2005. Available online: www.ccee.iastate.edu/reserach/lutz/homepage.html (accessed on 16 May 2018). 
27. Jones, C.S.; Davis, C.A.; Drake, C.W.; Schilling, K.E.; Debionne, S.H.; Gilles, D.W.; Demir, I.; Weber, L.J. Iowa Statewide Stream Nitrate Load Calculated Using In Situ Sensor Network. J. Am. Water Resour. Assoc. 2018, 54, 471-486. [CrossRef]

28. Tomer, M.; Dosskey, M.; Burkart, M.; James, D.; Helmers, M.; Eisenhauer, D. Methods to prioritize placement of riparian buffers for improved water quality. Agroforest. Syst. 2009, 75, 17-25. [CrossRef]

29. Correll, D. Principles of planning and establishment of riparian buffer zones. Ecol. Eng. 2005, 24, 433-439. [CrossRef]

30. Jha, M.; Gassman, P.; Arnold, J. Water quality modeling for the Raccoon River Watershed using SWAT. Trans. ASABE 2007, 50, 479-493. [CrossRef]

31. Gaffin, S.R.; Rosenzweig, C.; Kong, A.Y. Adapting to climate change through urban green infrastructure. Nat. Clim. Chang. 2012, 2, 704. [CrossRef]

32. Schäffler, A.; Swilling, M. Valuing green infrastructure in an urban environment under pressure-The Johannesburg case. Ecol. Econ. 2013, 86, 246-257. [CrossRef]

33. Spatari, S.; Yu, Z.; Montalto, F.A. Life cycle implications of urban green infrastructure. Environ. Pollut. 2011, 159, 2174-2179. [CrossRef] [PubMed]

34. Ray, D.E.; Schaffer, H.D. Des Moines' Water-Quality Suit Is Based on Drainage-Tile Water Not Stormwater. Available online: http:/ / www.agpolicy.org/weekpdf/782.pdf (accessed on 6 April 2018).

35. Redick, T.; Brooks, C. WOTUS Wars and Endangered Species: Where Will Farmers Find Their Legal High Ground? Nat. Resour. Environ. 2016, 31, 20.

36. Board of Water Works Trustees of the City of Des Moines, Iowa v. Sac County Board of Supervisors as Trustees of Drainage Districts 32, ..e.a. United States District Court for the Northern District of Iowa Western Division. Decided 17 March 2017.

37. Christen, B.; Dalgaard, T. Buffers for biomass production in temperate European agriculture: A review and synthesis on function, ecosystem services and implementation. Biomass Bioenergy 2013, 55, 53-67. [CrossRef]

38. Osborne, L.; Kovacic, D. Riparian vegetated buffer strips in water-quality restoration and stream management. Freshw. Biol. 1993, 29, 243-258. [CrossRef]

39. Christen, B. Tree Root Influences on Soil Physical Properties Under Shelterbelts on Pasture: Design and Evaluation of an Approach Using Dye Staining. Ph.D. Thesis, University of Wales, Bangor, UK, 2007.

40. Liang, W.; Kosugi, K.; Mizuyama, T. A three-dimensional model of the effect of stemflow on soil water dynamics around a tree on a hillslope. J. Hydrol. 2009, 366, 62-75. [CrossRef]

41. Olszewska, M.; Smal, H. The effect of afforestation with scots pine (Pinus sylvestris L.) of sandy post-arable soils on their selected properties. I. Physical and sorptive properties. Plant Soil 2008, 305, 157-169. [CrossRef]

42. Schultz, R.; Isenhart, T.; Simpkins, W.; Colletti, J. Riparian forest buffers in agroecosystems-Lessons learned from the Bear Creek watershed, central Iowa, USA. Agroforest. Syst. 2004, 61, 35-50.

43. Schoonover, J.E.; Williard, K.W. Ground water nitrate reduction in giant cane and forest riparian buffer zones. J. Am. Water Resour. Assoc. 2003, 39, 347-354. [CrossRef]

44. Vellidis, G.; Lowrance, R.; Gay, P.; Hubbard, R. Nutrient transport in a restored riparian wetland. J. Environ. Qual. 2003, 32, 711-726. [CrossRef] [PubMed]

45. Burt, T.; Pinay, G.; Matheson, F.; Haycock, N.; Butturini, A.; Clement, J.; Danielescu, S.; Dowrick, D.; Hefting, M.; Hillbricht-Ilkowska, A.; et al. Water table fluctuations in the riparian zone: Comparative results from a pan-European experiment. J. Hydrol. 2002, 265, 129-148. [CrossRef]

46. Diebel, M.; Maxted, J.; Robertson, D.; Han, S.; Handen, M. Landscape planning for agricultural nonpoint source pollution reduction III: assessing phosphorus and sediment reduction potential. Environ. Manag. 2009, 43, 69-83. [CrossRef] [PubMed]

47. Rao, N.; Easton, Z.; Schneiderman, E.; Zion, M.; Lee, D.; Steenhuis, T. Modelling watershed-scale effectiveness of agricultural best management practices to reduce phosphorus loading. J. Environ. Manag. 2009, 90, 1385-1395. [CrossRef] [PubMed]

48. Sharpley, A.; McDowell, R.; Kleinmann, P. Phosphorus loss from land to water: Integrating agricultural and environmental management. Plant Soil 2001, 237, 287-307. [CrossRef]

49. Cooper, A.; Smith, C.; Smith, M. Effects of riparian set-aside on soil characteristics in an agricultural landscape: Implications for nutrient transport and retention. Agric. Ecosyst. Environ. 1995, 55, 61-67. [CrossRef] 
50. Dorioz, J.; Wang, D.; Poulenard, J.; Trévisan, D. The effect of grass buffer strips on phosphorus dynamics e a critical review and synthesis as a basis for application in agricultural landscapes in France. Agric. Ecosyst. Environ. 2006, 117, 4-21. [CrossRef]

51. Hernandez, M.; Mitsch, W. Denitrification in created riverine wetlands: Influence of hydrology and season. Ecol. Eng. 2007, 30, 78-88. [CrossRef]

52. Addy, K.; Gold, A.; Christianson, L.; David, M.; Schipper, L.; Ratigan, N. Denitrifying bioreactors for nitrate removal: a meta-analysis. J. Environ. Qual. 2016, 45, 873-881. [CrossRef] [PubMed]

53. Sugg, Z. Assessing U.S. Farm Drainage: Can GIS Lead to Better Estimates of Subsurface Drainage Extent? World Resources Institute Report; World Resources Institute: Washington, DC, USA, 2007.

54. USDA-NRCS. National Resources Inventory: A Statistical Survey of Land Use And Natural Resource Conditions and Trends on U.S. Non-Federal Lands; USDA Natural Resources Conservation Service: Washington, DC, USA, 2006. Available online: https:/ / water.usgs.gov/GIS/metadata/usgswrd/XML/ (accessed on 6 April 2018).

55. Barrett, K. Water Quality Trading: What Works? What Doesn't? And Why Don't We Know This Already? 2016. Available online: https://www.forest-trends.org/ecosystem_marketplace/water-quality-trading-worksdoesnt-dont-know-already / (accessed on 16 May 2018).

56. Environmental Protection Agency. Water Quality Trading. 2017. Available online: https://www.epa.gov/ npdes/water-quality-trading (accessed on 16 May 2018).

57. Stephenson, K.; Shabman, L. Where did the agricultural nonpoint source trades go? Lessons from Virginia water quality trading programs. J. Am. Water Resour. Assoc. 2017, 53, 1178-1194. [CrossRef]

58. Samarasinghe, O.; Daigneault, A.; Greenhalgh, S.; de Oca Munguia, O.M.; Walcroft, J. Impacts of Farmer Attitude on the Design of a Nutrient Reduction Policy-A New Zealand Catchment Case Study. In Proceedings of the 56th Australian Agricultural and Resource Economics Society (AARES) Conference, Fremantle, Australia, 7-10 February 2012; p. 62.

59. Perez, M.; Walker, S.; Jones, C. Nutrient Trading in the MRB: A Feasibility Study Using Large-Scale Interstate Nutrient Trading in the Mississippi River Basin to Help Address Hypoxia in the Gulf of Mexico; World Resources Institute Report; World Resources Institute: Washington, DC, USA, 2013.

60. Jones, C.; Branosky, E.; Selman, M.; Perez, M. How Nutrient Trading Could Help Restore the Chesapeake Bay; World Resources Institute Working Paper; World Resources Institute: Washington, DC, USA, 2010.

61. Kaufman, Z.; Abler, D.; Shortle, J.; Harper, J.; Hamlett, J.; Feather, P. Agricultural costs of the Chesapeake Bay total maximum daily load. Environ. Sci. Technol. 2014, 48, 14131-14138. [CrossRef] [PubMed]

62. Wainger, L.A.; Van Houtven, G.; Loomis, R.; Messer, J.; Beach, R.; Deerhake, M. Tradeoffs among ecosystem services, performance certainty, and cost-efficiency in implementation of the Chesapeake Bay total maximum daily load. Agric. Resour. Econ. Rev. 2013, 42, 196-224. [CrossRef]

63. Greenhalgh, S.; Selman, M. Comparing water quality trading programs: what lessons are there to learn? J. Reg. Anal. Policy 2012, 42, 104.

64. Fisher-Vanden, K.; Olmstead, S. Moving pollution trading from air to water: Potential, problems, and prognosis. J. Econ. Perspect. 2013, 27, 147-171. [CrossRef]

65. Booker, J.F.; Young, R.A. Modeling intrastate and interstate markets for Colorado River water resources. J. Environ. Econ. Manag. 1994, 26, 66-87. [CrossRef]

66. Davies, B.R.; Thoms, M.; Meador, M. An assessment of the ecological impacts of inter-basin water transfers, and their threats to river basin integrity and conservation. Aquat. Conserv. Mar. Freshw. Ecosyst. 1992, 2, 325-349. [CrossRef]

67. Moore, I.; Grayson, R.; Larson, A. Digital terrain modeling: A review of hydrological, geomorphological, and biological applications. Hydrol. Process. 1991, 5, 3-30. [CrossRef]

68. Tarboton, D. A new method for the determination of flow directions and upslope areas in grid digital elevation models. Water Resour. Res. 1997, 33, 309-319. [CrossRef]

69. Tarboton, D. TauDEM Version 5. Available online: http://hydrology.usu.edu/taudem/taudem5/ downloads.html (accessed on 6 April 2018).

70. Schmitt, T.; Dosskey, M.; Hoagland, K. Filter strip performance and processes for different vegetation, widths, and contaminants. J. Environ. Qual. 1999, 28, 1479-1489. [CrossRef]

71. Peterjohn, W.; Correll, D. Nutrient dynamics in an agricultural watershed: observations on the role of a riparian forest. Ecology 1984, 65, 1466-1475. [CrossRef] 
72. Burkart, M.; James, O.; Tomer, M. Hydrologic and terrain variables to aid strategic location of riparian buffers. J. Soil Water Conserv. 2004, 59, 216-223.

73. Tomer, M.; James, D.; Isenhart, T. Optimizing the placement of riparian practices in a watershed using terrain analysis. J. Soil Water Conserv. 2003, 58, 198-206.

74. United States Geological Survey. The National Map. Available online: https://viewer.nationalmap.gov/ launch/ (accessed on 6 April 2018).

75. Iowa Department of Natural Resources. State Forest Nursery. Available online: http://www.iowadnr.gov/ Conservation/Forestry/State-Forest-Nursery (accessed on 6 April 2018).

76. Lowrance, R.; Leonard, R.; Sheridan, J. Managing riparian ecosystems to control nonpoint pollution. J. Soil Water Conserv. 1985, 40, 87-91.

77. Mayer, P.M.; Reynolds, S.K.; McCutchen, M.D.; Canfield, T.J. Meta-analysis of nitrogen removal in riparian buffers. J. Environ. Qual. 2007, 36, 1172-1180. [CrossRef] [PubMed]

78. United States Environmental Protection Agency. National Primary Drinking Water Standards. Available online: https:/ / www.epa.gov/ground-water-and-drinking-water/national-primary-drinking-waterregulations (accessed on 6 April 2018).

79. Schultz, R.; Collettil, J.; Isenhart, T.; Simpkins, W.; Mize, C.; Thompson, M. Design and placement of a multi-species riparian buffer strip system. Agroforest. Syst. 1995, 29, 201-226. [CrossRef]

80. Forestry Suppliers. Blue-X Tree Shelters. 2018. Available online: http://www.forestry-suppliers.com/ product_pages/products.asp? $\mathrm{mi}=8138$ (accessed on 6 April 2018).

81. Osenbaugh's Prairie Seed Farms. Prairie Seed Farms-Prairie Grasses. 2018. Available online: http:// prairieseedfarms.com/prairie-seed-farms-prairie-grass-seed/prairie-seed-farms-prairie-grass-seed.html (accessed on 6 April 2018).

82. West, D.; Kincer, D. Yield of switchgrass as affected by seeding rates and dates. Biomass Bioenergy 2011, 35, 4057-4059. [CrossRef]

83. Iowa State University Extenstion. Estimated Costs of Crop Production in Iowa-2017. Available online: https:/ / store.extension.iastate.edu/Product/Estimated-Costs-of-Crop-Production-in-Iowa-2017 (accessed on 6 April 2018).

84. Schary, C.; Fisher-Vanden, K. A new approach to water quality trading: applying lessons from the acid rain program to the Lower Boise River Watershed. Environ. Pract. 2004, 6, 281-295. [CrossRef]

85. King, D.M.; Kuch, P.J. Will nutrient credit trading ever work? An assessment of supply and demand problems and institutional obstacles. Environ. Law Rep. News Anal. 2003, 33, 10352-10368.

86. Selman, M.; Greenhalgh, S.; Taylor, M.; Guiling, J. Paying for Environmental Performance: Potential Cost Savings Using A Reverse Auction in Program Sign-Up; World Resources Institute, Policy Note; World Resources Institute: Washington, DC, USA, 2008.

87. Newburn, D.A.; Woodward, R.T. An ex post evaluation of Ohio's Great Miami water quality trading program. J. Am. Water Resour. Assoc. 2012, 48, 156-169. [CrossRef]

88. Cochran, B.; Logue, C. A watershed approach to improve water quality: case study of Clean Water Services' Tualatin River program. J. Am. Water Resour. Assoc. 2011, 47, 29-38. [CrossRef]

89. O'Grady, D. Sociopolitical conditions for successful water quality trading in the South Nation River Watershed, Ontario, Canada. J. Am. Water Resour. Assoc. 2011, 47, 39-51. [CrossRef]

90. Breetz, H.L.; Fisher-Vanden, K.; Jacobs, H.; Schary, C. Trust and communication: mechanisms for increasing farmers' participation in water quality trading. Land Econ. 2005, 81, 170-190. [CrossRef]

91. Mariola, M.J. Farmers, trust, and the market solution to water pollution: The role of social embeddedness in water quality trading. J. Rural Stud. 2012, 28, 577-589. [CrossRef]

92. United States Environmental Protection Agency. Frequently Asked Questions about Water Quality Trading. 2018. Available online: https:/ / www.epa.gov/npdes/frequently-asked-questions-about-water-qualitytrading\#top (accessed on 16 May 2018).

93. Des Moines Water Works. Five-Year Capital Improvement Plan; Des Moines Water Works: Des Moines, IA, USA, 2017.

94. Meinch, T. Water Works to End Direct Dumping of Nitrates Into River. Available online: https: / /www.desmoinesregister.com/story/news/2016/02/24/water-works-end-direct-dumping-nitratesinto-river/80811354/ (accessed on 6 April 2018). 
95. Angier, J.T.; McCarty, G.W. Variations in Base-Flow Nitrate Flux in a First-Order Stream and Riparian Zone. J. Am. Water Resour. Assoc. 2008, 44, 367-380. [CrossRef]

96. Claassen, R.; Cattaneo, A.; Johansson, R. Cost-effective design of agri-environmental payment programs: U.S. experience in theory and practice. Ecol. Econ. 2008, 65, 737-752. [CrossRef]

97. Feather, P.; Hellerstein, D.; Hansen, L. Economic valuation of environmental, benefits and the targeting of conservation programs: the case of the CRP. Agric. Econ. Rep. 1999, 778, 1-56.

98. Shortle, J.S.; Dunn, J.W. The Relative Efficiency of Agricultural Source Water Pollution Control Policies. Am. J. Agric. Econ. 1986, 68, 668-677. [CrossRef]

99. Harrington, W.; Krupnick, A.J.; Peskin, H.M. Policies for Nonpoint-Source Water Pollution Control. J. Soil Water Conserv. 1985, 40, 27-32.

100. Gianessi, L.P.; Peskin, H.M. Analysis of national water pollution control policies: 2. Agricultural sediment control. Water Resour. Res. 1981, 17, 803-821. [CrossRef]

101. Libby, L.W. Paying the nonpoint pollution control bill. J. Soil Water Conserv. 1985, 40, 33-36.

102. Parks, P.J.; Hardie, I.W. Least-cost forest carbon reserves: cost-effective subsidies to convert marginal agricultural land to forests. Land Econ. 1995, pp. 122-136. [CrossRef]

103. Darveau, M.; Beauchesne, P.; Belanger, L.; Huot, J.; Larue, P. Riparian forest strips as habitat for breeding birds in boreal forest. J. Wildl. Manag. 1995, 67-78. [CrossRef]

104. Moore, R.; Spittlehouse, D.; Story, A. Riparian microclimate and stream temperature response to forest harvesting: A review. J. Am. Water Resour. Assoc. 2005, 41, 813-834. [CrossRef]

105. Evans, I. Seven Ideas for Fixing Water in the United States. Available online: https:/ /www.newsdeeply.com/ water/community/2018/01/17/seven-ideas-for-fixing-water-in-the-united-states (accessed on 6 April 2018).

106. Poe, A.C.; Piehler, M.F.; Thompson, S.P.; Paerl, H.W. Denitrification in a constructed wetland receiving agricultural runoff. Wetlands 2003, 23, 817-826. [CrossRef]

107. Higgins, M.; Rock, C.; Bouchard, R.; Wengrezynek, B. Controlling agricultural runoff by use of constructed wetlands. In Constructed Wetlands for Water Quality Improvement; CRC Press: Boca Raton, FL, USA, 1993; pp. 359-367.

(C) 2018 by the authors. Licensee MDPI, Basel, Switzerland. This article is an open access article distributed under the terms and conditions of the Creative Commons Attribution (CC BY) license (http:/ / creativecommons.org/licenses/by/4.0/). 